\title{
James Clarence Mangan'ın Sûfîlerin Mânisi Başlıklı Şiirinin Kur'an-1 Kerim ve Sufîlik Bağlamında Metinlerarası Bir İncelemesi
}

\author{
Prof. Dr. Arda Arikan \\ Akdeniz Üniversitesi, Edebiyat Fakültesi \\ İngiliz Dili ve Edebiyatı Bölümü \\ ardaari@gmail.com
}

\author{
Kivılcrm Uzun \\ Alanya Alaaddin Keykubat Üniversitesi \\ Yabancı Diller Yüksekokulu \\ kivilcimuzun@hotmail.com
}

Öz

James Clarence Mangan (1803-1849) Orta Doğu'nun kültürel ve sosyal atmosferini edebi eserlerine konu etmiştir. Bir kısmının çeviri olduğunu iddia ettiği şiirlerin yanı sıra tamamıla kendisine ait olan şiirler de mevcuttur. Spiritüalizm ve mistisizme olan ilgisi sonucu Mangan, Orta Doğu merkezli kadim bir inanış olan ve Batı dünyasında sıklıkla İslam mistisizmi olarak adlandırılan Sûfîlik ile de özellikle ilgilenmişti. Aynı zamanda büyük Sûfî öğreticilerinin edebi külliyatına hakimdi ve Sûfî öğretilerini kendi ürettiği metinlerde de kullanmıştı. Bu metinlerden biri olan Sûfilerin Mânisi isimli şiiri, yedi bölüme ayrılmasıyla ve her bölümün kendi içerisinde yarı düzyazı yarı şiir biçiminde sunulmasıyla özellikle dikkat çekicidir. Düzyazı kısımları her seferinde "besmele" ile başlayan şiirin hem içerik hem biçem açısından incelenmeye ve metinlerarası bir okumaya ihtiyaç duyduğu gözlemlenmiştir. Bu çalışmada, metinlerarasılık bağlamında yürütülen inceleme sonucu şairin yedi bölüme ayırarak her bir bent öncesi verdiği düzyazıların Kur'an'1 Kerim'in belli başlı ayetlerine yapılmış birer anıştırma olduğu sonucuna varılmıştır.

Anahtar Kelimeler: Metinlerarasılık, Sûfîlik, Kur'an-1 Kerim, anıştırma, James Clarence Mangan.

\section{An Intertextual Analysis of James Clarence Mangan's The Soffees' Ditty in Relation to the Koran and Sufism}

\section{Abstract}

James Clarence Mangan (1803-1849) expressed the Middle East's cultural and social atmosphere in his literary works. Except for some poems claimed to be translations, he has written original poetry as well. As a result of his interest in spiritualism and mysticism, Mangan was particularly interested in Sufism, an ancient belief centered in the Middle East and frequently called Islamic mysticism in the West. He also had a grasp of the literary canon of the prominent Sufi teachers, and he used Sufi doctrines in the texts he produced. One of these texts, The Soffees' Ditty is exceptionally intriguing with its seven chapters including both prose and verse. Stylistically, prose sections begin with "Bismillah!", which requires further stylistic and intertextual analysis. Hence, the intertextual analysis conducted revealed that each section preceding the verse and written in prose include various allusions to specific verses of the Koran.

Keywords: Intertextuality, Sufism, the Koran, allusion, James Clarence Mangan. 


\section{GİRIŞ}

Sufîlik geleneksel olarak Türk ve İslam coğrafyasını ve dünyadaki diğer inançları etkilediği kadar modern Türk toplumunu ve edebiyatını da etkilemiş olan önemli bir İslam inancı ve pratiğidir (Altındiş, 2020). Bir İslam düşünce ekolü olan Sufîliğin 19. yüzyılın hemen tümü Katolik Hıristiyan olan İrlanda'sının edebiyatına güçlü bir şekilde yansımış olduğunun iddia edilmesi ilk başta okuyucuya şaşırtıcı gelebilir; ancak böylesi bir iddia, 19 . yüzyıl İrlanda'sının önemli şair ve yazarı James Clarence Mangan'ın (1803-1849) yazını dikkate alındığında sınanabilir bir düzleme kavuşur. Düzyazılarıyla olduğu kadar şiirleriyle de öne çıkan, edebi üretim açısından tüm verimlilik ve ustalığına rağmen yeterince ilgi görmemiş ve çok da araştırılmamış olan Mangan, İrlanda'nın siyasi bunalımlarına eleştirel ve mesafeli olarak yaklaşmış ve belki de bu yüzden İrlandalılar tarafından çekince oluşturan şair ve yazarlar kapsamında yer almıştır. Öte yandan Mangan, ekonomik, siyasi ve kültürel baskılarla İrlanda'yı etkisi altına almak isteyen İngiltere'yi topyekûn reddettiği için de İngilizler tarafından hak ettiği ilgiyi görememiştir. Eserlerinde sıklıkla Orta Doğu'yu konu almasına rağmen ülkemiz de dahil olmak üzere Orta Doğu coğrafyasında da ilgi görmemiş ve eserleri yeterince incelenmemiş olan Mangan, aslında İslam kaynaklarına ve özellikle Osmanlı şairlerine atıflar yapmış ve onların şiirlerini çevirerek yayımlamış bir yazın adamıdır. Bütün bunlara karşınyurt dışında, Mangan'ın yazınının İslam ile olan ilişkisi üzerine yayımlanmış tek bir çalışma dahi elimizde bulunmamaktadır.

Mangan'ın ilk ve en kapsamlı biyografisini yazmış olan O'Donoghue (1897), Mangan'ın dünya edebiyatı kanonundan dışlanmasının sebebinin ancak Mangan'ın hayat öyküsünün derinlemesine bir şekilde öğrenildiğinde anlaşılabilir olacağını ima eder. Orta Doğu'yu konu ettiği şiirlerinde kendini sıklıkla bu coğrafyada yaşayan dinsel inançlar, kültürler ve insanlarla özdeşleştirmiş, adeta onlardan biriymişçesine eserlerini icra etmiş olan Mangan'ın, özellikle Türk ve İslam coğrafyasına olan ilgisi ve bu ilginin eserlerine yansıması onun Osmanlı sultanlarına adadığı şiirlerinde bile görülmektedir. Son zamanda yayımlanan birkaç çalışma dışında, Mangan'ın eserlerinin eleştirel ve mukayeseli olarak çalışılmamış olması her şeyden önce Avrupa üzerindeki İslam ve Osmanlı etkisinin tam olarak anlaşılmasını da güçleştirmektedir.

Mangan'ın Sûfilerin Mânisi (The Soffees' Ditty) başlıklı şiiri hem içerik hem de biçem bakımından oldukça özgün bir şiir olup yarı düzyazı yarı şiir formunda yazılmış bir eserdir. Yedi bölüme ayrılan şiirin her bölümü düzyazı formunda yazılmış ahlaki bir öğretiyle sunulmakta ve bu öğretiler de Kur'an-1 Kerim'deki sureler gibi besmele ile başlamaktadır. Bu öğretiler zaman zaman kafiyelere dikkat edilerek yazılsa da çoğu kez nazım biçiminde değil; adeta bir sure görünümündedir. Her bir öğreti sonrası söyleyici ${ }^{1}$, benzer içerikte bir bent ile Sûfîlik öğretilerini sunmakta ve bunu Oryantalist bir bakış açısıyla ve belirgin bir ötekiden bahsederek değil, kendini Sûfîlerle özdeşleştirip 'biz' diyerek yapmaktadır. Mangan'ın tercih ettiği ve aynı zamanda Kur'an-1 Kerim ayet ve surelerine atıflar içermekte olan böylesi bir üslup, söyleyicinin kendisini de bir Sûfî olarak yansıtması ve dolayısıyla şiirin bir Sûfí'nin ağzından söylenmesi açısından da önem teşkil etmektedir. Bu çalışmada, Mangan'ın Sûfilerin Mânisi başlıklı şiiri Kur'an'ı Kerim ayetleri, Sûfîliğin bilinen özellikleri ve Genette'in metinlerarasılık (İng. intertextuality) kuramı çerçevesinde incelenmiştir.

1 Alanyazında, özellikle Batı Edebiyatı'nda kullanılan 'poetic persona/speaker' kavramı için farklı karşılıklar bulunmaktadır. Bu çalışmada, Kurt (2019, s. 175) tarafından önerilen 'söyleyici' ifadesi kullanılmıştır. 


\section{KURAMSAL ÇERÇEVE}

Edebiyatı bir yaşantılar, düşünceler ve fikirler birikimi sonucu ortaya çıkan ürünler toplamı olarak ele aldığımızda hiçbir metnin birbirinden tamamen bağımsız bir şekilde gelişemeyeceği fikrine yaklaşmış oluruz. Edebi metin okuma ve anlam çıkarma sürecine bu tür bir yaklaşım getiren çağdaş kuramcılar, birbirleriyle olan ilişkileri çözüldüğü takdirde, metinleri okuma ve yorumlama sürecinin daha anlamlı bir hale geleceğini savunmuş ve "metin okumanın bizi metinsel ilişkiler ağının içerisine soktuğunu" ileri sürmüşlerdir (Graham, 2011, s. 1). Gittikçe popülerlik kazanan ve genellikle postmodern kuram çerçevesinde anılan metinlerarasılık, edebi eserlerin okuma, inceleme ve eleştiri süreçlerine farklı bir bakış açısı getirmektedir. Çoğu kez birden fazla metni birlikte okumaya ve bu şekilde değerlendirmeye sebep olan metinlerarasılık, "birçok çeşit metnin (sözlü, görsel, edebi, sanal) diğer metinlere yapılmış atıflar içermesi" (Childs ve Fowler, 2006, s. 121) gerçeğinden yola çıkarak bu atıflara anlam yükleme çabasına işaret eder. Terim olarak metinlerarasılık, ilk kez 1966 yılında, henüz bir öğrenci olan Julia Kristeva tarafından, Rus kuramcı Mikhail Bakhtin üzerine yaptığı bir sunum esnasında ortaya atılmıştır (BeckerLeckrone, 2005, s. 13). Terimi post-yapısalcı bir yaklaşımla ele alan Kristeva daha sonrasında ortaya attığı bu kuramsal yapıyı, Dilde Arzu: Edebiyat ve Sanata Göstergebilimsel Bir Yaklaşım başlıklı kitabında kuramsal bir çerçeveye oturtarak şu şekilde tanımlar:

Metin (...) bir üründür ve bu şu anlamlara gelir: Birincisi, metnin yerleştirildiği dil tekrar dağıtılabilen bir yapıdadır (yıkıcı-yapıcı), ve bu nedenle dilbilimsel kategorilerden ziyade mantıksal kategorilerle yaklaşılması gerekir ve ikinci olarak ise metinlerin takası anlamına yani metinlerarasılık anlamına gelir: var olan bir metnin boşluklarında, diğer metinlerden alınmış muhtelif ifadeler kesişir ve birbirlerini etkisizleştirir (Kristeva, 1980, s. 36).

Metinlerarasılık kavramı ortaya konulmadan çok önceleri metinler arası ilişki başta edebiyat olmak üzere birçok alanda kendisini elbette göstermiştir; ancak Kristeva'ya kadar bu ilişkileri kuramsal bir çerçevede incelemek mümkün olmadığından, Kristeva'nın ismi bu alanda, özellikle edebi metinlere getirdiği kuramsal yaklaşım açısından son derece önemlidir. Metinlerarasılık zaman içinde yeni terim ve kavramlarla zenginleşmiştir. Örneğin, metinselaşkınlık kuramı "bir metni diğer bir metinle belirgin veya gizli bir ilişki içerisine oturtan her şey" olarak açılanırken (Genette, 1997, s. 1), bu çerçeveden bakıldığında, Kristeva'nın metinlerarasılık kuramı metinlerin birbirleriyle olan tüm ilişkilerini açıklamakta yetersiz bulunmuştur. Öte yandan, üst-metinsellik kuramının ilkini metinlerarasılık olarak isimlendiren ve terimi de "bir metnin bir diğerindeki asıl varlığı" olarak açıklayan Genette $(1997$, s. 1) alıntılama, aşırma ve anıştırma kavramlarını da bu başlık altında inceler. Bu sebeple, Kristeva'dan farklı olarak tanımladığı metinlerarasılık kavramının sınırları ve içeriği daha belirgin olduğundan, Mangan'ın Sûfilerin Mânisi başlıklı şiirinin her bir bölümünün başında düzyazı olarak verilen öğretilerde Kur'an-1 Kerim'e yapılan anıştırmalar, Genette'in metinlerarasılık kuramı çerçevesinde incelenecektir. Böylesi bir çerçeve tek tek anıştırmaların anlamının bulunmasından ziyade, anıştırmaların yekûnunun metindeki anlamlarına ve bu anlamların edebi ve pratik işlevlerine odaklanır. $\mathrm{Bu}$ çerçeve, aynı zamanda, incelenen metnin yazarının anıştırmaları kasıtlı olarak bir amaç yüzünden bir araya getirmiş olduğu savı üzerine temellendirilir; çünkü "bir şey, diğer bir metnin içine dâhil edildiğinde o şeyin nasıl bir çerçeve içinde sunulacağına ilişkin birtakım seçenek ve alternatifler vardır; dolayısıyla bu alternatiflerden birinin seçimi, aktarımı yapan

SEFAD, 2021; (46): 23-42 
kişinin tasarrufunu yansıtmaktadır" (Özer, 2008, s. 310). Bu yüzden, bir anıştırma ya da alıntı, kasıtlı olarak yazar tarafından kullanıldığında, yazarın metinde hedeflediği bir amacı gerçekleştirmesi amacını taşıdığını gösterir diyebiliriz.

Metinlerarası çalışmaların temel yöntemi incelenen metinde yer alan anıştırmaları bulmak ve kaynak metnin incelenen metinle karşılaştırılarak anıştırmaların ne şekilde ve hangi anlamlarda kullanıldı̆̆ı üzerine savlar üretmektir. Anıştırma, en yalın haliyle, "Metnin dişındaki bir metinde geçen bir insana, yere ya da olaya atıfta bulunmak" demek olup bazen de "önemli bir fikri özetlemek" (Quinn, 2006, s. 20) amacını taşıyabilir. Bu çalışmada incelenecek olan ve bu çalışmanın da odağını oluşturan anıştırmaları mezkûr eserde bulmak ve sorgulamak metni yorumlama sürecine değer katması açısından oldukça önemlidir. Anıştırma, en basit tanımla, dolaylı bir ima yöntemiyle yapılan atıflara tekabül eder. Bir diğer metinlerarası ilişki biçimi olan alıntı çoğu kez görünür bir şekilde ve hatta tırnak işareti içine alınarak yapılırken, anıştırmada kaynak, yani gönderme yapılan metin, açıça belirtilmez. Anıştırmalar çoğu zaman örtük olduğundan, bir metnin içerisindeki anıştırmayı belirlemek bazen entelektüel ve bilimsel anlamda bir bilgi birikimi gerektirebilir ve bu sebeple, atıf yapılan metni ve dolayısıyla da anıştırmanın kendisini belirlemek bazen zor olabilir. Anıştırma "yalnızca bir göndergenin yerini tutmaktan öteye giden çağrışımları gerektirmesi açısından dolaylı olan bir atıf" (Irwin, 2001, s. 293) olarak tanımlanırken anıştırmaların tek yönlü çalıştığı belirtilir. Diğer bir deyişle, "Eğer A metni, B metnini anıştırıyorsa, o halde B metni, A metnini anıştırmaz" (Irwin, 2001, s. 289). Edebiyat ve bilimde sıklıkla kullanılan anıştırmalar sadece bu alanlarla sınırlı kalmayıp siyaset, felsefe, sosyoloji, antropoloji gibi daha birçok alanın alanyazınında okuyucunun karşısına çıkmakta ve ilk bakışta fark edilmesi için belli bir alanda bilgi birikimi gerektirmektedir. Konumuz olan mezkûr eserin incelenmesinde önemli bir yer tutan anıştırma kavramının daha etkin bir şekilde anlaşılması için Sûfîlik ve Mangan hakkında kısa ve öz bir bilgi vermek yerinde olur.

\section{SÛFÎLİK VE MANGAN}

Sûfîlik hakkında yapılan çalışmalarda Sûfîliğin birden fazla kolu olduğu belirtilir ancak yine de bir düşünce ve inanç sistemi olarak Sûfîlik başlığ 1 altında toparlanabilen akımların belirgin benzerlikler taşıdıkları da bilinmektedir. Elçibey ve Kemaloğlu'nun (2014) da belirttiği üzere:

Sûfilik ya da sûfizm VIII. yüzyıldan başlamış, günümüze kadar Yakın ve Orta Doğu'da, Kuzey Afrika ülkelerinde toplumun bütün alanlarm oldukça etkileyen bir sosyal güç olmuştur. Dünyanın birçok önemli âlimleri sûfîliği inceleyip, onun birkaç kolunu, tuttuğu yolu, düşünce dizginini açılasalar da öyle bir ortak sonuca, herkesin kabul edeceği söze gelip çıkmamışlardır (s. 6).

"Sûfî kimdir?" sorusuna yanıt verilirken "kendini saflaştırana Sufî denir" diyen Elçibey ve Kemaloğlu (2014, s. 8), Ömer Sühreverdi'nin Sufî tanımlamasının Sufîlik ile ilgili tartışmalarda genel olarak kabul edilebilir olduğundan da bahseder. "Tasavvuf" kelimesinin Yunanca "Sofos" kelimesinden türeyerek Arapça'ya girdiği kabul edilir (Gökpınarlı, 1985, s. 9). Tarihsel süreç içerisinde sözcüğün kullanımına baktığımızda Sûfîlik inancını benimseyenlere derviş denildiği ve özellikle de ilk dervişlerin üstlerine sadece tek parça bir kıyafet giyerek, hiçbir şekilde mülkiyet edinmeden diyar diyar gezdikleri ve gittikleri yerlerde insanları inançları doğrultusunda bilgilendirmekten başka amaç gütmedikleri görülmektedir. İlk olarak 9. yüzyılda, İran ve Türkistan merkezli olarak Orta Doğu'da ortaya 
çıkan Sûfî inancı, bu coğrafyadan önce Afrika'ya, Asya'ya ve sonrasında Avrupa'ya yayılmıştır. Günümüzde ise dünyanın pek çok yerinde giderek popülerlik kazanmış, birçok Türk ve yabancı araştırmacının ilgi konusu olmuştur. Bir semazen olan Celaleddin Rûmî'nin İngilizceye çevrilmiş eserleri ve şiirleri, bugün Amerika Birleşik Devletleri'nde en çok satan eserler arasında sayılmakta (Renard, 2009, s. 2) ve ülkenin çeşitli eyaletlerinde, Sûfî öğretileri üzerine şekillenmiş uygulamalarla meditasyonların yapıldığı toplamda 115 adet Uluslararası Sûfî Merkezi bulunmaktadır (Gowins, 2009, s. 30). Mesnevi yapıtıyla hemen hemen herkesçe bilinen Mevlâna Celaleddin Rûmî haricinde önde gelen Sûfîler arasında, Abdal Musa, Cüneyd Bağdâdî, Hacı Bektaş, Gazali, İbn-i Arabi, Yunus Emre, Ahmed Yesevî gibi daha birçok isim sayılabilir.

Bugün birçok kesim tarafından tanınan, eserleri geniş bir okuyucu kitlesi tarafından okunan ve öğretileri yine birçok yerde konuşulup tartışlan Sûfî dervişler hayattayken pek çok eser vermişlerdir. Onların yazıları, kitapları, deyişleri ve kuşaktan kuşağa aktarılan öğretileri, Sûfî inancının tanınması ve günümüze kadar ulaşmasında büyük rol oynamışlardır. Sûfî dervişlerin yazdıklarına bakıldığında hemen hemen her Sûfînin inancını kendi kelimeleriyle tanımladığı görülmektedir. Tasavvuf ve Sûfîliği en erken dönemde tanımlayanlardan biri, 9. yüzyılda yaşamış Fars kökenli bir Sûfî olan Cüneyd-i Bağdâdî' dir:

\begin{abstract}
Tasavouf, varlı̆̆ından ölmen, Tanr ile dirilmendir. Tasavouf iyi huydur; iyi huyların ne kadar çoğalırsa Tasavoufta o kadar ilerlemiş olursun. Sûfí yer yüzüne benzer; ona her kötü şey atılır, fakat ondan ancak güzel ve temiz şeyler biter; üstünde iyi de gezer, kötü de. Bulut gibidir Sûfi, her yere, her şeye gölge salar; yă̆mur gibidir, herkesi sular. Sûfìy dışı bezenmiş gördün mü, bil ki içi harap olmuştur (akt. Gölpınarlı, 1985, s. 11).
\end{abstract}

Tasavvuf ve Sûfîliği iyiden ve güzelden yana olmak olarak kısaca özetleyen Cüneyd-i Bağdâdî'nin ve diğer Sûfîlerin tanımlarından da anlayacağımız üzere, Sûfî inancının temelinde, insanları Allah yolundan saptıran tüm dünyevi zevklerden uzaklaşıp ruhu terbiye etmeye dayanan ruhani ve psikolojik bir içsel yolculuk yatar. Bu yolculuğun sonunda Sûfîlerin nihai varacağı yer insan-ı kâmil olmak, yani mükemmel insan mertebesine ulaşmaktır.

Sûfîlerin Kur'an-1 Kerim ile olan ilişkilerinin ortaya konulması çalışmamızın içeriğinin daha iyi anlaşılması açısından büyük önem teşkil eder. Öncelikle, her ne kadar Sûfîler için daima yol gösterici bir rehber olsa da Kur'an-1 Kerim'de Tasavvuf veya Sûfîlik terimlerinin geçmediği bilinmelidir. Öte yandan, ilk zamanlardan başlayarak önemli Sûfî yorumcuları Kur'an-1 Kerim üzerine oldukça etkili yorumlar yapmışlardır (Renard, 2009, s. 193). Ayrıca yine birçok Sûfî, Kur'an'ın tefsirini yapmış veya edebi eserlerinde Kur'an'dan alıntılar ve anıştırmalar yaparak, bu kutsal kitabı öğretilerine temel kaynak olarak göstermişlerdir. Kur'an-1 Kerim'de bahsedilen ve örneklendirilen ahlak, erdem ve iyilik gibi kavramları, kendilerine özgü öğreti ve felsefe ile birleştirerek hayata geçirmeye çabalayan dervişler, aynı zamanda Kur'an-ı Kerim'den alıntılayıp ezberden okudukları ayetler sebebiyle coşkun bir ruh hal içine girerler ve böylece bir tür meditasyon durumuna geçerlerdi (Schimmel, 1978, s. 26). Bu nedenle, Sûfîlik ve öğretilerini anlamak ve uygulamak için önce Kur'an-1 Kerim'in öğretilerini anlamak gereklidir. Ancak, Mangan'ın Sûfîlerin Mânisi başlıklı şiirinde, Kur'an-1 Kerim ayetlerine yaptığı anıştırmaları anlamlandırmadan önce Sûfîliğin tarihi ve Mangan'ın Sûfîlik ile ilişkisinin genel hatlarıyla bilinmesi yararlı olur.

SEFAD, 2021; (46): 23-42 
Batı'da çoğunlukla, İslam mistisizmi olarak isimlendirilerek ruhani yönünün altı çizilen Sûfîlik, bazı metinlerde Arapça kökenli bir kelime olan Tasavouf olarak da adlandırılır. Türkiye Diyanet Vakfı Ansiklopedisi'nde ise Tasavvuf, "İslam'ın zâhir ve bâtın hükümleri çerçevesinde yaşanan mânevî ve derunî hayat tarzı" olarak tanımlanır. Sûfîlik kelimesinin kökeninin nereden geldiğine dair görüşler bugüne kadar birçok tartışmanın konusu olmuştur. Kesin bir sonuca ulaşlamamasına rağmen en çok kabul gören açıklamalardan biri kelimenin Arapça kökenli "Sûf" yani "Yün" kelimesinden gelmesidir. Sûfîler, yünden yapılma kıyafetler giydikleri için bu açıklama ilk bakışta akla yatkın gelse de bazı tarihçiler bu ve buna benzer açılamaları reddetmişlerdir. Sûfîlerin "kendilerini tamamen ibadete adamış" kişiler olduğu ve "sof (sûf) giymeleri ve herkes gibi gösterişli elbiselerden kaçınmaları” onları diğer gruplardan ayırmaktadır (Soya, 2015, s. 36).

Gösterişten uzak durma ve dünyevî olanı reddetme alışkanlığı salt Sufîlerde değil, Mangan'ın yaşamında da görülür. Şiirleri ile düzyazılarında mistik ve ruhsal unsurlara sıklıkla yer veren ve belki de Sûfîliğe yönelik ilgisi sebebiyle, Kur'an-1 Kerim'i okumuş olduğu anlaşılan James Clarence Mangan, hem imgelem yoluyla hem de biçemsel olarak mistik unsurları eserlerine katarak gizemlerle dolu bir yazın dünyası oluşturmuş ancak böylesi uhrevî bir süreçte açlık, sefalet ve yalnızlık hali ile yaşamıştır ki bu yönüyle yaşam biçimi olarak Mangan'ın bir derviş gibi yaşadığı görülür. Giyim ve yaşam tarzının dışında, Mangan'ın Türkçe, Farsça ve Arapçadan çevirdiğini iddia ettiği birçok şiirinde Sûfî inanç ve öğretilerinden de izler görülür. İrlandalı politikacı ve şair Thomas D'Arcy McGee, Mangan'ın ölümünden kısa bir süre önce yayınladığı bir makalede Mangan'ı dervişlere benzeterek şu ifadeleri kullanır: "Bu şairin, gerçekliğin kötülüğünden ideale yönelen, hazır ancak oldukça mutsuz bir çıkış yolu bulduğu bir gerçektir ve oldukça aşina olduğu dervişlerinkine benzeyen bu ilhamı, afyon yemesinden kaynaklanmaktadır" (akt. O’Donoghue, 1987, s. 109).

Sûfîlerin önemli bir özelliğinin "sof (suf) giymeleri ve herkes gibi gösterişli elbiselerden kaçınmaları" (Soya, 2015, s. 36) olduğu yukarıda belirtmiştir. Bu noktada Mangan hakkında önemli bir ayrıntının Mangan'ın kişiliğini anlamamızda ve incelediğimiz şiirin de açımlanmasında yararlı olacağı kanaatindeyiz. Yaşadığı dönemde, Mangan'ı diğer insanlardan görsel olarak ayıran en önemli unsur kıyafetidir. O'Donoghue'ya (1897) göre eskici bir Yahudi gezgin satıcısından Mangan'ın satın alarak giydiği kıyafet İngiliz dilinde "cloak" olarak geçen bir üstlüktür ki bu kıyafeti gören herkesin şaşırdığı bilinmektedir. Kanımızca bu kıyafet bir nevi pelerinden ziyade bir Orta Doğu kıyafeti olan cübbedir; çünkü o dönemde yaşayan bir İrlandalının gördüğünde şaşıracağı bir üstlüktür bu. Bu açıdan bakıldığında Mangan'ın en azından simgesel olarak giydiği kıyafet yoluyla kendini tasavvuf ehli olarak gördüğü bile söylenebilir.

Yazınında, Orta Doğu coğrafyasına geniş ölçüde yer vererek bu coğrafyanın kültürü ve tarihini şiirlerinde ve düzyazılarında sıklıkla yansıtan Mangan bir şiirinde şöyle der: "Seni alçak Avrupalı! / Rahatsız edemezsin dolayısıyla, / Benim gibi yaşlı bir Müslümanı / Kafasında Kızılbaş türbanıyla." Yesevi geleneğine bağlı Sûfîlere verilen isim olan Kızılbaşlık veya bugün bilinen ismiyle Alevilik bu şekilde Mangan'ın şiirlerinde yer almıştır; ancak burada dikkat edilmesi gereken husus, şiir söyleyicisinin kendisini bir Kızılbaş addetmesidir ki bu da 19. yüzyılın Katolik İrlanda'sına ters düşen, anakronistik bir yaftalamadır. Mangan'ın 1838'de yazdığı ve Hüdayi'den çevirdiğini söylediği Passage veya 1840 'ta yazdığ 1 The Daunishmend's Lamentation gibi birçok farklı şiirinde, bir Sûfî nidası olan ve Sûfîlerin 
ibadetlerinde, günlük yaşamlarında ve ruhani şiirlerinde sıklıkla yer verilen "Ya Hu!" seslenişine rastlarız. Şairin 1838 ' de yazdığı The City of Truth başlıklı şiirinde geçen "whom Allah" ifadesi, özellikle sözün cümledeki yeri göz önüne alındığında, "Hu Allah!" nidasını çağrıştırmaktadır (Akgül ve Arıkan, 2019). Bu çalışmada incelenen Sûfîlerin Mânisi başlıklı şiir şairin teması doğrudan doğruya Sûfîlik olan tek şiiri olsa da Mangan diğer birçok şiirinde gerek tema ve içerik, gerekse söz sanatları ve motifler açısından Sûfîliğe ve Sûfî öğretilerine oldukça fazla yer vermiştir. Ocak 1844'te Dublin Üniversitesi Dergisi'nde (The Dublin University Magazine) yayımlanan Literae Orientales başlıklı makale dizisinin beşincisi olan Osmanl Şiiri (Ottoman Poetry) başlıklı yazısında Sûfilerin Mânisi isimli şiirini yayımlamış olan şair, şiirin hemen arkasından okuyucusunu Sûfîlik konusunda şöyle bilgilendirmiştir: "Sûfîler, kendilerini aralıksız duaya, çileye ve ilahi kemale ermeye adamış olan dervişlerin bir koludur ve sıklıkla, (...) tövbekâr bir şekilde nefislerinden feragat etme çabalarında şevk ve sebat sergilerler" (Mangan, 1844, s. 545). Aynı makale içerisinde yayınladığ 1 şiirinde kullandığı temalardan ve sonraki açıklamalardan da anlaşılacağı üzere Mangan, Sûfîlik, dervişler ve Sûfî öğretileri konusunda da oldukça bilgi sahibiydi.

\section{İNCELEME, BULGULAR VE TARTIŞMA}

Mangan, Sûfilerin Mânisi isimli şiirini yedi başlığa ayırmış ve her başlığı numaralandırmıştır. Her bir bölüm önce kafiyesiz yazılmış bir veya iki cümleden oluşan, çalışma boyunca öğreti olarak adlandıracağımız bir düzyazıyla, bu düzyazı bölümlerinin tamamı da tıpkı Kur'an-1 Kerim'de surelerin başladığı gibi "Bismillah!" diyerek besmele ile başlamaktadır. Arkasından gelen uyaklı ve ustaca yazılmış bent ile içerik bakımından ilişkili olan bu bölümler belli başlı bir sureden birebir çeviri olmasalar da işaret ettikleri öğreti ve ögütler bir veya birden fazla ayeti anıştırmaktadır. Besmele ile başlayan ve nadiren uyaklı yazılan bu bölümleri, toplamda altı satırdan oluşan ve her bir satırı 14 hece içeren ve orijinal dilinde aa-bb-cc uyak düzeni ile yazılmış bir bent takip eder.

İlk altı bölümün son bendini sürekli olarak "İşte bunlar bizim söylediğimiz mâninin tonu ve melodisi" olarak bitiren Mangan son bendi ise "Bunlar bizim söylediğimiz mâninin tonu ve melodisi olsun" şeklinde bitirmeyi tercih etmiştir. Burada Mangan'ın "mâni" olarak adlandırdığı ve "biz" diyerek sahiplendiği şiirini "ton" ve "melodi" sözleri ile bir müzik eseri ya da şarkı olarak tasavvur ettiği görülebilir. Bu noktada, geleneksel bazı Ortaçağ İslam akımlarının aksine müziğe önem vermiş bulunan Sûfî pratiğinin müziğe bakış açısını hatırlamakta fayda vardır, çünkü “Ortaçağ'da mûsikînin insanı ibadetten, Allah'ı düşünmekten alı koyduğunu iddia edenlerin tersine Mevlânâ Celâlüddîn Rûmî'nin ve başka Sûfîlerin sırf ilâhî sevgi ile vecde gelip, mûsikî ahengi ve ritmi ile semâ ettikleri" bilinmektedir (Üçok, 1968, 155). Mangan'ın şiirini bir nevi şarkı olarak adlandırmasının böylesi bir Sûfî anlayışına benzerlik arz etmesi dikkat çekicidir.

Bu son dizelerde en dikkat çekici kısım ise şiir söyleyicisinin kendisini bir Sûfî gibi yansitarak mâniyi sahiplenmesi ve "bizim mânimiz" demesidir. Bu son dizelerden anlayacağımız üzere, söyleyici kendini Sûfîler ile özdeşleştirmiş ve Doğu'ya ait bu şiirini Oryantalist bir bakış açısıyla değil,içerden birinin ağzıyla yazmıştır. Ayrıca burada, biçemsel olarak Kur'an-1 Kerim'de Allah'ın "biz" ifadesini kendisini nitelemede kullandığından yola çıkarsak, Mangan'ın Kur'an-ı Kerim'den ne derece etkilenmiş olduğunu görebiliriz. Genel itibariyle tasavvuf ehlinin öz nefislerini öne koymaktan imtina ederek "ben" yerine "biz" diye kendilerinden bahsettikleri düşünülebilir, ancak "biz" ifadesinin, Mangan'ın adını şiirde zikrettiği Hallac-1 Mansur ile özdeşleşen En-el Hakk görüşünün dilsel bir uzantısı 
olduğu da iddia edilebilir. Bütün bu bilgiler dikkate alınarak, daha anlaşılabilir olması açısından içeriğine ve uyak düzenine dikkat ederek Türk diline aktardığımız Sûfilerin Mânisi isimli şiirin içindeki öğreti kısımlarının anıştırdığı sure ve ayetler ile arkasından gelen şiir bentleri, bölüm sirasına uygun olarak incelenecektir.

İncelenen şiir ile tasavvuf düşüncesi ve Kur'an-1 Kerim'in içerik olarak karşılaştırması en belirgin olarak nefis kavramını işaret etmektedir. İnsanların nefislerini terbiye etmeleri Kur'an-1 Kerim ve Hz. Muhammed yoluyla ve insanları uyarmak amacıyla iletildiğinden, nefis kavramının İslam düşünce ve pratiğinde önemli biryer tuttuğunu söyleyebiliriz. . Örneğin, Bakara suresi 119. ayette "İnan olsun ki, biz seni hak üzere bir müjdeci ve uyarıcı olarak gönderdik" (Kur'an-1 Kerim 2: 119) ve A'raf suresi 2. ayette "Bir kitaptır bu; sana indirildi, onunla uyarıda bulunasın diye ve inananlar için bir öğüt ve düşündürme olarak... O halde, bundan dolayı göğsünde bir sıkıntı olmasın" (Kur'an-1 Kerim 7: 2) denilmekte ve bu yolla uyarma görevinin önemi belirgin bir şekilde ortaya konulmaktadır. İncelediğimiz şiirdeki söyleyici de şiirde,Sûfî öğretisinin merkezini oluşturan nefsini kontrol etme ve bir amaç uğruna dünyevi tüm zevk ve alışkanlıklardan vazgeçme çabasını böylesi bir uyarının önemli bir unsuru olarak ele alır:

Bismillah! Uyarılmıştın sen, Ey Sûfî!

Kanaatkarlığın, kendi içinde ne kadar harika olsa da,

Seni kâmil yapmayacağı konusunda.

“Bektaşiliğin yanı sıra Kalenderîlik ve Haydarîlik gibi birçok tarikatın mensubu dervişlerin dünya malından vazgeçmeleri, fakir, mütevâzı bir hayat yaşamaları önemli kavram ve davranışlar arasındadır" (Altıer, 2008, s. 105). Sûfî inanç ve pratiğinin merkezinde de insan-ı kâmil mertebesine ulaşma amacının yattığından bahsetmiştik. Mangan'a göre, Sûfîlerin dışardan gözlemlenebilen nefse hakimiyet gayeleri her ne kadar ulu bir gaye olsa da kâmil insan olmak için daha fazlası gereklidir. Kendini bilmek, iç dünyamızı düzenlemek ve terbiye etmek gibi erdemler ile şiirin ilk bölümünde Mangan'ın yazdığı bu satırlarda geçen kanaatkarlık, gösterişten uzak durma ve nefsine hakimiyet gibi konular Sûfîliğin merkezinde olduğu kadar Kur'an-1 Kerim'de sıklıkla sahip olması ögütlenen erdemlerdendir. Örneğin, Tâ Hâ Suresinde şöyle der: "Buna inanmayan ve nefsinin arzusuna uyan kimseler, seni ondan sakın alıkoymasın, sonra helâk olursun!" (Kur'an-1 Kerim 20: 16). Benzer şekilde nefsine hâkim olamamakla ilgili bir başka sure ise Rûm Suresidir: "Fakat, zulmedenler bilgisizce nefislerinin arzularına uydular. Allah'ın bu şekilde saptırdığı kimseleri kim doğru yola iletir? Onların hiçbir yardımcıları yoktur" (Kur'an-1 Kerim 30: 29). Davud Peygamber ile ilgili olan Sâd Suresi de yine nefsine hâkim olmanın önemini vurgular: “Ona dedik ki: 'Ey Dâvûd! Gerçekten biz seni yeryüzünde halife yaptık. İnsanlar arasında hak ile hüküm ver. Nefis arzusuna uyma, yoksa seni Allah'ın yolundan saptırır. Allah'ın yolundan sapanlar için hesap gününü unutmaları sebebiyle şiddetli bir azap vardır'" (Kur'an-1 Kerim 38: 26). Sûfîliğin, Kur'an-1 Kerim'i bir rehber olarak gördüğü ve öğretilerini de yine bu kutsal kitap etrafında şekillendirdiği göz önünde bulundurulursa, Mangan'ın bir sure gibi başlayan metinlerinin Kur'an-1 Kerim'in belli başlı surelerini anıştırması daha büyük bir anlam taşıyacaktır.

Bu sebeple, öğretisinden hemen sonra gelen kısımda Mangan, bir Sûfî olmak ve bir Sûfî gibi yaşamak için nelerin gerekli olduğunu ustalıkla seçtiği kelimeler ve bu kelimeleri maharetle kullanarak yazdığı satırlarla tek tek sayar okuyucusuna: 
Çuhalar, oruçlar, kahveye karşı bir yemin ve gece nöbetleri,

Günahlardan arındırsa da, yapmaz kimseyi bir Sûfî.

Aşırılıktan tamamen uzaklaşmaktan fazlası zorunlu

Uysallık, Yokluk, Cesaret ve Tevazu

Bilgelik, ve Sessizlik, ve Sabır, ve durmaksızın Dua yani,

İşte bunlar bizim söylediğimiz mâninin tonu ve melodisi.

Şiirin bu bendi Mangan'ın Sûfî inanç ve pratiğinden ne anladığını göstermesi açısından çok önemlidir. "Çuhalar, oruçlar ve kahveye karşı bir yemin" diyerek Sûfîlerin yaşam tarzlarına atıfta bulunan söyleyici, kendi düşüncesine göre bir Sûfîyi Sûfî yapan tüm özellikleri art arda sıralayarak, aslında bu yolculuğun ruhsal bir yolculuk olduğunun da altını çizmektedir. Daha önce belirttiğimiz "Sûfîyi dışı bezenmiş gördün mü, bil ki içi harap olmuştur" (akt. Gölpınarlı, 1985, s. 11) deyişine paralel olarak süssüz bir yaşamı tercih etmenin bir Sûfî için yeterli olamayacağını savunan Mangan, bu dizelerinde diş görünümden ziyade içsel zenginliğin ve adanmışlığın yanı sıratasavvuf ehlinin sabır ve dua gibi deneyimlerinin de öneminin de altını çizer. Bu tarz bir düşünüşün, serbest düşünceye özgürlük getiren ve bireysel adanmışlı̆̆a kapı açan tasavvufî görüşlere (Noyan, 1999) uygun olduğunu belirtmekte yarar vardır.

Sûfîler kendi içsel yolculuklarında da mükemmeliyete, uyuma ve huzura kavuşmalıdırlar. Yine bu dizelerde geçen uysallık, tevazu, sabır gibi erdemler Kur'an-1 Kerim ayetlerinde sık sık altı çizilen erdemlerdendir. Örneğin, Furkân Suresi tevazu göstermek konusunda şöyle der: "Rahmân'ın kulları, yeryüzünde vakar ve tevazu ile yürüyen kimselerdir. Cahiller onlara laf attıkları zaman, 'selâm!' der, geçerler" (Kur'an-1 Kerim 23: 63). Sabır konusunda ise şöyle yazar: "Allah'a ve Resûl'üne itaat edin ve birbirinizle çekişmeyin. Sonra gevşersiniz ve gücünüz, devletiniz elden gider. Sabırlı olun. Çünkü Allah sabredenlerle beraberdir" (Kur'an-1 Kerim 8: 46). Şiirin bu ilk bölümünde Mangan, Sûfîlere öğüdünden sonra yazdığı dizelerde de Kur'an-1 Kerim'de sıklıkla bahsedilen ve insanı ruhsal olarak olgunluğa eriştirecek olan meziyetlerin altını çizmektedir. Öte yandan Mangan, bu kısım aracılığıyla şiirini kurguladığı düzlemde, bir taraftan amentüsünü okuyucuyla paylaşır ve bir anlamda Sûfî pratiğinin sinırlarını Kur'an-ı Kerim'in çizdiği bir üslupla yeniden yorumlar.

Şiirin ikinci bölümü günah işlemenin ve günah olduğunu bile bile bir davranışa devam etmekte ısrar etmenin sakıncalarının altını çizer. Yine Besmele ile başlayan bu kısım şöyledir:

Bismillah! Sakının daima yaşamaktan

Tek bir günahın rutin işleyişinde;

Küçükse de günahın kendisi

Sürekli tekrarı yapar onu en feci.

Nisâ Suresi, bahsedilen küçük günahlar ile ilgili: "Eğer size yasaklanan günahların büyüklerinden kaçınırsanız, sizin küçük günahlarınızı örteriz ve sizi güzel bir yere koyarız" (Kur'an-1 Kerim 4: 31) dese de Mangan'a göre günah küçük de olsa, tövbe edilmediği ve sürekli tekrar edildiği durumda kabul görmez. Bu öğretisi aynı zamanda tıpkı Hûd Suresi'nde de belirtildiği gibi tövbe etmenin önemini anlatır: “Ey kavmim! Rabbinizden bağışlanma dileyin, sonra O'na tövbe edin ki, üzerinize bol bol yağmur göndersin ve 
gücünüze güç katsın. Günahkârlar olarak yüz çevirmeyin" (Kur'an-1 Kerim 11: 52) ve "Rabbinizden bağışlanma dileyin, sonra da O'na tövbe edin ki sizi ömrünüzün sonuna kadar güzel bir şekilde yararlandırsın ve her fazilet sahibine faziletinin karşılığını versin. Eğer yüz çevirirseniz, ben sizin adınıza büyük bir günün azabından korkuyorum" (Kur'an-1 Kerim 11: 3). Mangan, Allah'ın merhametinin altının çizildiği çeşitli surelerde öğütlenen, samimiyetle tövbe edildiğinde günahlarının bağışlanacağı inancını kendi kelimeleriyle şiirinde şöyle yansıtmıştır:

Vah haline bir kötülükle diğerini defedenlerin!

Uzak olsun düşüncelerinden bu lanet yanılgı, ey kardeşim!

Sök çıar kalbini, ve tövbe et sahip olduğu ve sevdiği her şeye

Suçlu boşluklarında bir günah beslemektense.

Yama ve tamirdense, yeni kıyafetler giymektir daha asili:-

İşte bunlar bizim söylediğimiz mâninin tonu ve melodisi.

Söyleyici, şiirinin ikinci bendinin üçüncü satırında "Sök çıkar kalbini ve tövbe et sahip olduğu ve sevdiği her şeye" diyerek aynı zamanda dünyevi zevklere tövbe etmenin, dolayısıyla nefsine hâkim olmanın önemini de bir kez daha hatırlatmaktadır. Meryem Suresi, dünyevi zevklerden ayrılamayanlara, nefsine hâkim olamayanlara dair şöyle der: “Onlardan sonra, namazı zayi eden, şehvet ve dünyevî tutkularının peşine düşen bir nesil geldi. Onlar bu tutumlarından ötürü büyük bir azaba çarptırılacaklardır" (Kur'an-1 Kerim 19: 56). Bu dizeyi ve Meryem Suresini birlikte okuduğumuzda Mangan'ın vermek istediği mesajı yine bir Kur'an-1 Kerim suresini anıştırarak ilettiğini açıkça görebiliriz.

Şiirinin ikinci bölümüne yine benzer bir giriş yaparak, Sûfîler için de oldukça önemli olan günah ve tövbe konusunu bu şekilde şiirine konu eden söyleyici, şiirinin üçüncü bölümünde ise maddiyattan, maddiyatla birlikte gelen güçten ve dahi bu güce tapınmaktan sakınılması gerektiğinden bahseder:

Bismillah! Ey Sûfî! Gözlerinle her buluştuğunda

Paranın 1şıltısı, yüzünü çevir!

Koynunda yılan bile para kesesinden

Senin için daha iyidir.

Özellikle birer gezgin ve öğretmen olan Sûfîlerin, üstlerinde sadece bir parça yünden yapılma giysiyle, diyar diyar dolaşarak insanları aydınlatan ve bilgilerini paylaşan sofular oldukları bilinmektedir. Dolayısıyla, söyleyicinin bu öğüdünde bahsettiği paraya yüz vermemek ve mülk edinmemek Sûfî öğretisinde önemli bir anlayışa işaret eder. Benzer şekilde Kur'an-ı Kerim de yeryüzünde mülk edinmenin sakıncalarından, Fâtır Suresinde: “(...) İşte bu, Allah'tır, Rabbinizdir. Mülk yalnızca O'nundur" (Kur'an-1 Kerim 35: 13) olarak bahseder. Aynı şekilde, paraya, mala, mülke düşkünlük Haşir Suresi'nde de kesinlikle reddedilerek, bu hırslardan kurtulmanın mükafatlandırılacağı belirtilir: "Her kim nefsinin hırsından, mala olan düşkünlüğünden kendini kurtarırsa, işte felaha, kurtuluşa, mutluluğa erenler onlar olacaktır" (Kur'an-1 Kerim 59: 9). Bakara Suresi'nde ise yine bu konuyla ilgili: "Benim ayetlerimi az bir fiyatla, yani dünya menfaati karşılığında satmayın" (Kur'an-1 Kerim 2: 41) denir. Söyleyici, gözünü para hırsı bürümüş insanların önünde sonunda hileye, sahtekarlığa yöneleceğini, dünyevi her türlü zevk ve menfaatten uzak durması gereken bir Sûfînin paraya da yüz vermemesi gerektiğini şu bentle tekrar eder: 
Para (dedi Seyyid Alaaddin) bir kanser gibi yer ruhu,

Her kim severse parayı, Ben-Manser'den daha suçlu

Sakınırdın sen, Ey, Sûfî! Geceleri koltuklarından

Kötülükle boğulanlarla dalaşma tuzağından,

İsteme ve yüklenme, uzak tut haraç ve hileyi-

İşte bunlar bizim söylediğimiz mâninin tonu ve melodisi.

Şiirin genelinde örtük alıntı yapan Mangan, daha önce de belirttiğimiz gibi iki kere doğrudan alıntılama yolunu tercih etmiştir. Bunlardan ilkini, yukarıda verilen üçüncü bölümün nazım kısmında görmekteyiz: "Para (dedi Seyyid Alaaddin) bir kanser gibi yer ruhu" satırında geçen şahıs muhtemelen hayatı hakkında kısıtlı bilgiye sahip olduğumuz Seyyid Alaeddin Ali Semerkandi'dir. Sûfî çevrelerince sıklıkla kullanılan Seyyid lakabı, Hz. Muhammed'in soyundan gelenleri işaret etmesi dışında, Diyanet Vakfı Ansiklopedisi'ne göre: "efendi, bey, önder, sahip, faziletli, kerim" gibi anlamlara gelir. Mangan'ın dizelerinde bahsettiği Seyyid Alaeddin Ali Semerkandi'nin Horasan Erenlerinden biri olduğu, Tasavvuf yolunda ilerlediği ve "temel İslam bilimlerinin yanında edebi, felsefi bilgiler de okumuş, mezhep tarafgirliği olmayan, meselelere geniş açıdan bakan bir alim olduğu" söylenmektedir (Yaşar, 2016, s. 262).

Mangan'ın da bu dizelerle, söyleyicisi üzerinden öğütlediği gibi hileden, haraçtan ve her türlü sahtekarlıktan uzak durulması gerekliliği Kur'an-1 Kerim'de de sıklıkla vurgulanmıştır. Özellikle, gözünü para hırsı bürümüş tüccarların daha çok para kazanma hırsı uğruna ölçü ve tartıda hile yapmaları Mutaffifîn Suresinde asla hoş görülmez: "Ölçüde ve tartıda hile yapanların vay hâline!" (Kur'an-1 Kerim 83: 1). Kuran'da hile ve her türlü fesatlıktan uzak durmak: "Yeminlerinizi aranızda hile ve fesat sebebi yapmayın. Sonra sağlamca bastıktan sonra ayaklarınız kayar da Allah yolundan sapmanız sebebiyle kötü azabı tadarsınız. Ahirette de sizin için büyük bir azap vardır" (Kur'an-1 Kerim 16: 94) şeklinde de buyrulur. Bu bentte, bahsedilen ayetleri anıştıran ögütler veren söyleyicinin ikinci dizede bahsettiği ve hile yapanların "ondan daha suçlu" diyerek ismini andığı BenManser, şairin Dublin Üniversitesi Dergisi'nde Literae Orientales yazı dizisinin beşinci makalesinde belirttiği üzere, önemli Sûfîlerden biri olan Cûneyd-î Bağdâdî'nin öğrencisi ve "En-el Hakk" yani "Ben Hakk'ın kendisiyim" dediği için idam edilen Hallac-1 Mansur'dan başkası değildir. Bahsi geçen metinde ismi tam olarak "Abou-Mogheedh-Huseyn-BenManser-al-Halladj" şeklinde verilen Hallac-ı Mansur ile ilgili olarak "9. yüzyılda yaşamış olan ünlü Arap büyücü ve mistik. Ruhun doğasıyla ilgili, anlaşılamayan metafiziksel dini öğretilerini ilan etme suçundan, Halife Muktedir-Billâh saltanatı tarafından ölüme mahkûm edilmiştir" (Mangan, 1844, s. 543) denilmiştir. Şiirinde parayı sevenlerin, Hallac-1 Mansur'dan daha suçlu olduğu fikrini savunarak, fikirleri ve inancı yüzünden yargılanan Hallac-1 Mansur'un parayı sevenlerden daha masum olmasına rağmen trajik bir ölüme mahkûm edildiğini bir kez daha okuyucuya hatırlatırken şair, aynı zamanda İslam'ın Sûfî çizgide bir yorumlamasını da yapmış olur.

Sûfîlik tarihi ve önde gelen Sûfîler hakkında çokça bilgisi olduğu belirgin olanMangan, şiirin dördüncü bölümüne de yine besmele ile başlar ve Kur'an-1 Kerim'de sıkça kullanılan iki sıfatla Allah'ı anar:

Bismillah! Yoktur güç ve akıl 
Yüce ve Büyük Allah'tan başka! Sen, Ey

Sûfî, kilden bir varlıktan başka hiçsin; dolayısıyla,

Gururundan hoşnut olma!

Birçok surede, Allah'ın sıfatları olarak kullanılan "Yüce" (İng. high) ve "Büyük" (İng. great) kelimeleri Kur'an-1 Kerim surelerinde Allah'ı anma ve sesleniş için o kadar sıklıkla kullanılıyor ki bu sıfatların da birer anıştırma örneği olduğunu söylemek herhalde çok yanlış olmazd1: "Gökleri ve yeri koruyup gözetmek O'na güç gelmez. O, yücedir, büyüktür" (Kur'an-1 Kerim 2: 255). Tıpkı Kuran'da seslenildiği gibi yaratıcısına seslenen söyleyici, şiirinin dördüncü bölümünde de Sûfîlere, insanın yaradılıştan aciz ve zayıf olduğunu hatırlatarak, böbürlenmemelerini öğütler. İnsanların, bir çeşit toprağın su ile karışımıyla oluşan kilden (İng. clay) yaratıldığ 1 fikri ise yine Kur'an'da sıklıkla belirtilmektedir: “(...) Seni topraktan, sonra bir damla döl suyundan yaratan, sonra da seni eksiksiz bir insan şeklinde düzenleyen Allah'ı inkâr mı ediyorsun?" (Kur'an-1 Kerim 18: 37). Benzer şekilde, Fâtır Suresi de bu konuya değinir: "Allah, sizi önce topraktan, sonra da az bir sudan yarattı" (Kur'an-1 Kerim 35: 11). Bu sureler gibi başka surelerde de insan yaradılışıyla ilgili benzer bilgiler verilmektedir ve bu şiir bağlamında ele alındığında Mangan'ın insanın yaratılışını Kur'an-1 Kerim'den alımladığı şekilde aktardığı görülmektedir.

Gururun hoş görülmemesi gerektiğini ve tevazu göstermenin önemini şiirinin dördüncü bölümünün girişindeki öğretisinde vurgulayan söyleyici bu satırların arkasından gelen bentte şöyle yazar:

Gururu kenara bırak, ki o ruhun katili:

Kibirli Kırlangıç çamura çok batar ve sstıraplı bulur her şeyi.

Mütevazı diye ininde elmas hala parıldarken,

Dev gibi duran gurur direğidir yıkılması gereken.

Eğil! ve gittikçe azalsın yükün deveninki gibi

İşte bunlar bizim söylediğimiz mâninin tonu ve melodisi.

$\mathrm{Bu}$ satırlarda birden fazla kez yapılan kişileştirme ile kırlangıcın, ruhun katili olan gururu yüzünden istırap çektiği ve çok değerli bir maden olmasına rağmen yeraltında yatarak tevazu gösteren elmasın bu sebeple hala parıldayabildiği ileri sürülmüştür. İnsanın ruhsal yükü bir deveninkiyle kıyaslanmış ve ancak eğildikçe, mütevazı oldukça bu ruhsal yüklerin azalacağı vurgulanmıştır. Mangan'ın bu dizelerle altını çizdiği gurur ve kibirden uzak durma ve tevazu gösterme gibi kavramlar yine Kur'an-1 Kerim'de insanlığa sıklıkla ögütlenir.Kur'an-ı Kerim'deki bazı sureler kibirli insanlara bunun yersizliğini hatırlatarak, Allah'ın kibri asla kabul etmediği ve sevmediğini vurgular: "Yeryüzünde böbürlenerek yürüme. Çünkü sen yeri asla yaramazsın, boyca da dağlara asla erişemezsin" (Kur'an-1 Kerim 17: 37) ve "Küçümseyerek surat asıp insanlardan yüz çevirme ve yeryüzünde böbürlenerek yürüme! Çünkü Allah, hiçbir kibirleneni, övüngeni sevmez" (Kur'an-1 Kerim 31: 18). Şiirin ilk bölümünü incelerken tevazu olmak konusunda örnek gösterilen Furkân Suresi gibi, Secde Suresi de mütevaziliğin öneminin altını çizer: "Bizim âyetlerimize ancak, kendilerine bu âyetlerle öğüt verildiği zaman secdeye kapanan, kibirlenmeksizin Rablerine hamd ederek tespih edenler inanırlar" (Kur'an-1 Kerim 32: 15). Sonuç olarak, Mangan'ın bu satırlarında Sûfîlere mütevazı olma yönünde verdiği öğütler, yukarıda belirtilen Kur'an-1 Kerim surelerini ve ayetlerini anıştırmaktadır diyebiliriz. 
Tevazu göstermenin erdemini şiirinde birden fazla kez vurgulayan Mangan, beşinci bölümün düzyazı kısmında farklı bir konuya değinir ve şeytana uymak yerine Allah yolundan sapmadan ıstırap çekmenin Allah katında mutlaka mükafatlandırılacağını belirtir. Bu yolu seçmeyenlerin cezası ise elbette cehennemdir:

Bismillah! Şeytan, Ey Sûfî! deneyecek kuşkusuz

Seni pek sefil etmeyi. Ama avun; çünkü

Yedi cehennem kapıları kapandı arkalarından

Aşağıya inenlerin buradan.

Bu satırlarda geçen yedi rakamı Kur'an-1 Kerim'de özel bir yere sahiptir ve birçok ayette, birçok farklı konuda sıklıkla tekrarlanmaktadır (bkz. Kur'an-1 Kerim 17: 44, 15: 87, 25 : 17, 23: 86, 31: 27, 65: 12, 12: 43-48). Göklerin yedi kattan yaratıldığı da yine kutsal kitapta defalarca belirtilmektedir. Mangan'ın son cümlesinde belirttiği, şeytana uyanların gönderileceği ve sonradan kapılarının kapanacağı "yedi cehennem" tanımlaması ise doğrudan Hicr suresini anıştırmaktadır: "Şüphesiz cehennem, onların hepsinin buluşacağ yerdir. Onun yedi kapısı vardır ve her kapıya onlardan bir grup ayrılmıştır" (Kur'an-ı Kerim 15: 43-44). Yedi rakamı İslamiyet dahil birçok din ve kültürde ilahi bir simge olarak kabul edilmektedir (Gezer, 2015, s. 478) ancak burada Mangan'in cehennemin yedi kapis1 nitelemesinin direkt olarak Kur'an-1 Kerim'den alındığı ve bu yüzden de bir anıştırma olduğu görülebilmektedir. Bu satırlardan sonra gelen bentte söyleyici, yeryüzünde istırap çekenlerin Allah tarafından yalnız bırakılmayacağının altını çizer:

Bitkin mi düştün anılardan, korkulardan ve kuruntulardan ötürü?

Kederlenme! geçmiş devrin Sûfîleri ve azizleri de böyleydi çünkü.

Herkes terk etmeli Hayat meskenini, ama gidenler bulamaz

Bir pasaport Cehenneme, gönül yarasından daha işe yaramaz.

Şeytan esir etti, ve Istırap Tanrı'nın azat biçimi-

İşte bunlar bizim söylediğimiz mâninin tonu ve melodisi.

Görüldüğü üzere Sûfîleri çektikleri acılardan ötürü teselli etmeye gayret eden söyleyici, çile çekmeyi, ıstırabı ve acıyı Sûfî öğretisinin bir nevi gerekliliği saymaktadır. Ona göre, geçmişteki Sûfîler de acı ve ıstırap içinde yaşamalarına rağmen şeytana uymadıkları ve doğru bildikleri yoldan şaşmadıkları için ahirette ödüllendirilmişlerdir. Bundan ötürü, söyleyici Sûfillere kendilerini yalnız ve terk edilmiş hissetmemelerini, sebat ve sabır göstermelerini öğütleyerek ıstırap ve acının şeytanın oyunu olduğunun altını çizer. Söyleyicinin bu öğüdü Kur'an-1 Kerim'den bazı sureleri anıştırmaktadır: "Allah'a verdiğiniz sözü az bir karşılığa değişmeyin. Eğer bilirseniz, şüphesiz Allah katında olan sizin için daha hayırlıdır. Sizin yanınızdaki tükenir, Allah katında olan ise kalıcıdır. Elbette sabredenlere, yapmakta olduklarının en güzeliyle mükâfatlarını vereceğiz" (Kur'an-1 Kerim 16: 95-96). Kutsal kitap ve çeşitli hadislerle vurgulanan ve Mangan tarafından şairane bir dille tekrarlanan bu öğüt, doğru yoldan sapmayıp sabır gösteren insanlara yeryüzünde çekilen acı ve çile karşılığında ahirette mutluluk ve huzur vaat etmektedir.

Şiirin altıncı bölümünün başında, Mangan'ın doğrudan verdiği ikinci alıntı karşımıza çıar:

Bismillah! Istırap içinde olman senin için daha iyidir. 
Süleyman-Bin-Davud'un da dediği gibi,

Kalp, çehrenin üzüntüsüyle iyileşir.

Bu dizelerde geçen Süleyman Bin Davud, Hz. Davud'un oğlu olan ve Kur'an-1 Kerim'e göre İsrailoğullarına gönderilen peygamber Hz. Süleyman'dan başkası değildir. Bilindiği üzere, Süleyman Bin Davud ismindeki bin, Arapça ibn yani oğul kelimesinden türemekte ve bu nedenle aslında ismin anlamı "Davud'un oğlu Süleyman" anlamına gelmektedir. Söyleyicinin Hz. Süleyman'dan alıntılayarak söylediği: "Kalp, çehrenin üzüntüsüyle iyileşir" cümlesi Kur'an-1 Kerim'de geçmemektedir ancak, Hz. Davud'a indirilen ve Vaiz kitabı olarak da bilinen Zebur'da şu cümleler yer alır: “Üzüntü gülmekten iyidir/Çünkü yüz mahzun olunca yürek sevinir" (Vaiz 7: 3) ki Zebur'da yer alan vaizlerin bir kısmı Hz. Süleyman'a atfedilmiştir ve Mangan'ın bu dizelerinde geçen cümlenin yer aldığı vaiz de bunlardan biridir. Görüldüğü üzere, Mangan bu şiirinde yalnızca Kur'an-1 Kerim surelerine anıştırma yapmakla kalmayıp, Musevilikte kutsal sayılan Zebur'dan da alıntılara yer vermiştir. Bu da Kur'an-1 Kerim'de tekrar tekrar seslenilen Kitap ehlinin şair tarafından hatırlanması ve ilahi mesajın kapsayıcılığını işaret etmesi açısından önemlidir.

Altıncı bölümde, Zebur'dan alıntılanan cümlenin yer aldığı yazıdan sonra gelen şiir, bir önceki bölümde yer alan bent ile aynı temaya değinir. Bu bentte de dünyada acı çeken ancak doğru yoldan şaşmayan insanların öteki dünyada huzura erişeceklerinden söz edilir ve inananların sabrederek bu ıstıraplara katlanmaları gerektiği öğütlenir:

Şeyh'in kabrini aydınlatan yalnız bir lamba gibi,

Kasvetli bir müzede saklanmış değersiz bir maden gibi

Gece yarısından önceki parlak ayın sabahla harmanlandı̆̆ı gibi

Parlar Keder Kadehinde ruhun saf incisi!

Bu dünyada yas tutanlar sonsuz zevklerle bulacak teselli,

İşte bunlar bizim söylediğimiz mâninin tonu ve melodisi.

Hz. Süleyman'dan yaptığı alıntı da bu dizelerde anlatmak istediğine benzer bir içerik taşır. Söyleyici bu dizelerinde birçok kez teşbih (İng. simile) olarak adlandırılan söz sanatından faydalanarak, şiirin ikinci bölümünde "kardeşim" diye seslendiği Sûfîlere "Bu dünyada yas tutanlar sonsuz zevklerle bulacak teselli" diyerek sabrı ve sebatı öğütlemektedir. Mangan’ın şiirinin son, yani yedinci bölümü şu satırlarla başlar:

Bismillah! Tıpkı İnsanoğlunun ne ektiyse onu biçmesi gibi,

düşünceleri ve amelleri de öteki dünyaya

gelir onunla; ve bunların iyi veya kötü olmasına göre

kendisi de sonsuza kadar mutlu veya sefil olur.

İyice düşün bunu; ve bırak her bir fani saat

seni şu korkunç gerçekle daha derinden etkilesin:

Bedeli zamandır ahiretin.

$\mathrm{Bu}$ satırların en başında geçen, insanoğlunun yeryüzünde işlediği günahların ve sevapların öldükten sonra ahirete kendisiyle beraber taşınarak bunlara göre yargılanacağ 1 inancı Kur'an-1 Kerim'in şu ayetlerini anıştırır: “İman edip salih ameller işleyenlere, kendileri için; içinden ırmaklar akan cennetler olduğunu müjdele" (Kur'an-1 Kerim 2: 25). 
Yine aynı surede şu ifadeler yer alır: "Evet, kötülük işleyip suçu benliğini kaplamış ve böylece şirke düşmüş olan kimseler var ya, işte onlar cehennemliklerdir. Onlar orada ebedî kalacaklardır. İman edip salih ameller işleyenler ise cennetliklerdir. Onlar orada ebedî kalacaklardır" (Kur'an-1 Kerim 2: 81-82). Elbette ahiret kavramı İslamiyet dahil diğer semavi dinlerde de görülen bir kavramdır. Ancak şiirin bir Sûfî ağzından yazılması ve içerdiği diğer Sûfî öğretileri dışında Kur'an-ı Kerim'de (diğer kutsal kitaplarda olmayan bir şekilde) özellikle kullara "düşünme" ve akıl kullanma yetileri sıktıkça hatırlatıldığı için (Kur'an-1 Kerim 76: 29; Kur'an-1 Kerim 2: 73; Kur'an-1 Kerim 3: 118; Kur'an-1 Kerim 74: 55; Kur'an-1 Kerim 7: 184) Mangan'ın bu dizeleri yazarken ve özellikle de “İyice düşün bunu” derken diğer kutsal kitaplardan ziyade Kur'an-1 Kerim'den esinlendiğini savunmak pek de yanlış olmayacaktır. Şiirde son bölümün öğretisi "Bedeli zamandır ahiretin" cümlesi ile biter ve bu cümle Câsiye Suresindeki şu ayeti anıştırmaktadır: "Dediler ki: 'Dünya hayatımızdan başka hayat yoktur. Ölürüz ve yaşarız. Bizi ancak zaman yok eder'" (Kur'an-1 Kerim 45: 24). Mangan'ın ismi geçen ayete yaptığı bu örtük atıf ve ayetin kendisi, bedenin ve ruhun yok oluşu üzerinde geçen zamandan daha büyük etkisi olan başka hiçbir şey olmadığının altının çizmektedir.

Bu çalışmanın başında Cüneyd-i Bağdâdî'nin tasavvuf ve Sûfîliği iyiden ve güzelden yana olmak olarak açıkladığını belirtmiştir. Mangan da şiirinin son kısmını, iyilik ve kötülügün çatışmasına ayırır ki bu kısımda bu çatışma hem 'nimet' ve 'lanet' ve hem de 'iyi' ve 'kötü' zıtlaşması eksenindedir. Söyleyici şiirini bitirirken, daha önce her bölümün şiir kısımlarını bitirdiği aynı cümleyi biraz değiştirir. "İşte bunlar bizim söylediğimiz mâninin tonu ve melodisi" demek yerine bir dilekte bulunur ve en başından beri seslendiği Sûfîlere geçen zamanın değerini anımsattıktan sonra şiirini şöyle bitirir:

Sarfiyattır hayat sonsuz nimetlere veya lanetlere-

İyi veya Kötü - Ahiret Bankası hangisini öderse.

Sen, o zaman, Ey Sûfî! iyi bak geçirdiğin her anına,

Ellerin coşsun ve mükafatın şahane olsun,

Yüzün duvara baktığında ve sancıların arttığında,

Bunlar bizim söylediğimiz mâninin tonu ve melodisi olsun.

Mangan'ın biçemsel olarak şiirlerinin son dizelerini şiirinin tümünün bir özeti ve konu ile ilgili nihai görüşünü aracısız olarak aktarma yeri olarak kullandığı bilinmektedir. Bu son bent de şiirin tümünün bir özeti gibidir. Tek bir dizede söyleyici, geçen zamanın değerini Sûfîlere hatırlatmakla kalmamış, ahiret inancının ve öteki dünyadaki deneyimlerin, bu dünyada yapılan iyilik ve kötülükler sonucunda belirleneceğinin de altını bir kez daha çizmiştir. Ancak bu ödeme, "Ahiret Bankası hangisini öderse" denilerek, sır olarak kalan, bilinemez ve sonu Sûfîler tarafından bile kestirilemeyen bir gerçekliğe işaret edilerek geçiştirilmiştir. Böylesi bir yaklaşım, "Tanrı kavramını sevgi üzerinden" yorumlayan, "Allah'ı, korkulacak değil sevilecek bir kutsal Sevgili, kavuşup birleşilmesi özlenen bir Asli Ruh olarak" tanımlayan tasavvuf düşüncesine de uyan niteliktedir (Mut ve Akkuş, $2016 \mathrm{~s}$. 145). Ayrıca, mutsuz veya ıstıraplı bir ruh halindeyken bu şiirde, söyleyicinin de deyimiyle mânide geçen öğretilerin hatırlanması ve bu öğretilere inan ve sebatla devam edilmesi gerekliliği Sûfîlere son bir kez daha hatırlatılmaktadır. Biçemsel olarak yine bu son kısımda, ömrü acılarla geçmiş olan şair, izlemesi gereken yolun bu olduğunu kendisine de hatırlatmaktadır diyebiliriz. 


\section{SONUÇ}

Bu çalışmada Mangan'ın Orta Doğu temalı orijinal şiirlerinden biri olan Sûfilerin Mânisi başlıklı şiir Kur'an-1 Kerim ayetleri ve tasavvuf inancının bilinen özellikleri ile Gerard Genette'in metinlerarasılık kuramında belirttiği üzere şiir içeriğinde yer alan anıştırmalar üzerinde durularak incelenmiştir. Çalışmanın sonucunda, Mangan'ın mezkûr şiirinde kendisini bir Sûfî yerine koyduğu ve her bir şiir bölümünün başında sunduğu öğretilerin Kur'an'ı Kerim'in belli başlı ayetlerinden türetilmiş birer anıştırma (İng. allusion) olduğu sonucuna varılmıştır.

Mangan'ın yedi bölüme ayırdığı ve her bölümü kafiye kullanmadan düzyazı formunda yazdığı bir öğreti ile hemen ardından gelen ve belli bir uyak düzenini takip eden altı dizelik bentlerdenoluşan şiirinde, Sûfî öğretisinde insan-ı kâmil olmak için gereken sabır, günahlardan arınmak, tövbe etmek, kibirden uzak durmak, mütevazı olmak, mülkiyetten uzak durmak ve zamanın kıymetini bilmek gibi erdemleri ince ince ve ustalıkla adeta bir nakış gibi işlediği dizeleriyle okuyucusuna sunmaktadır. Son tahlilde, Mangan'ın yarattığı şiir söyleyicisinin kendisini bir Sûfî olarak nitelediği, Sûfí'likten ve Sûfî'lerden "biz" diye bahsettiği ve bilinen Sûfî inanç ve pratiğine sahip çıtığı ve bunu yaparken de Kur'an-1 Kerim bilgisinden yararlandığı açıkça görülmüş̧ür.

Mezkûr şiir ile Kur'an-1 Kerim arasındaki ilişkileri ortaya koyabilmek adına metinlerarası bir okuma yapıldığında, şiir söyleyicisinin Sûfî öğretilerini sunarken sıklıkla Sûfîlerin temel kitabı olan Kur'an-ı Kerim'in sure ve ayetlerine anıştırma yaptığı sonucuna varılmıştır. Hatta Mangan'ın Kur'an-1 Kerim ile şiiri arasında bağ kurduğu anıştırmaların yanı sıra, şiirinde iki kez doğrudan alıntı yapmış olduğu görülmüştür. Bunlardan biri, önde gelen Sûfîlerden biri olan Seyyid Alaeddin Ali Semerkandî'den, diğeri ise Hz. Süleyman'dan doğrudan alıntılanan kısımlardır. Her ne kadar semavi dinlerin kutsal saydığı diğer kitaplarda da benzer temalara ve erdemlere rastlansa da içeriğinde Sûfîlik ve Sûfî öğretileri olan bu şiirin içerdiği anıştırmaları belirlemek için öncelikle Sûfîlerin de rehber aldıkları Kur'an-1 Kerim'e bakmak gerektiği açıktır. Şiirinde kendisini Sûfîlerle özdeşleştiren ve şiiri de Sûfî bir kimsenin ağzından söyleyen Mangan'ın Kur'an-1 Kerimaracılığıyla ortaya koyduğu anıştırmalarla Sûfî öğretilerini şiirinde ustalıkla ve şairane bir dille yansıttığı görülmektedir. Mangan, bu yolla, tıpkı önde gelen Sûfî öğreticilerinin de yaptığı gibi şiirinin öğütlediği tüm erdemlere kaynak olarak bir nevi Kur'an-1 Kerim'i göstermiştir.

Dünyada oldukça tanınır olan ve değişen dünyaya ayak uydurmakta sıkıntı yaşayan insanlara yol göstermesi açısından günden güne öğretileri özellikle günümüzde tekrar hatırlanan Sûfîliğin, kâmil insan olma yolunda insanlığa verdiği öğütler bugün de geçerliliğini korumaktadır. Yeryüzünde bir insanın sahip olması gereken erdemleri ve bunu gerçekleştirme yolundaki uygulamaları öğretmesi açısından belki de bugün, Mangan'ın maharetle yazdığı bu şiir, Sûfîleri anmak, öğretilerini hatırlamak ve hem dünyada hem ahirette insanlığa yakışan güzel huyları bir kez daha anımsamak açısından da yararlı olacaktır. Bütün bunlara ek olarak Mangan'ın İslam ve tasavvufa ait imge ve söylemleri ile dolu bu şiirini okumak da İslam düşünce ve pratiğinin 19. yüzyıl İrlanda'sının (ve belki de Avrupa'sının) toplumsal şuuruna edebiyat yoluyla ne şekilde katkıda bulunduğunun ortaya konulması açısından da oldukça önemlidir. 


\section{SUMMARY}

James Clarence Mangan (1803-1849) was an Irish writer known to be a Catholic, although no first-hand record exists to suggest his religious ideas and feelings. Mangan's poetry includes some poems he claimed to be translations, most of which carry the names of the poets from the Islamic world. However, some of his works are considered original poems as well. Mangan's verse centers on themes, motifs, symbols, and characters originating from the Medieval period of the Middle East. In this cultural, religious, and social atmosphere dominating his literary works, some of Mangan's poems can be read as though a Muslim poet penned them because of their Islamic content. As his interest in spiritualism and mysticism is visible in his verse, it can equally be argued that Mangan was particularly interested in Sufism and, for some others, in Islamic mysticism. Mangan's verse also shows that he had a grasp of the literary canon of the prominent Sufi teachers, and he used Sufi doctrines in the texts he produced. One of these texts, The Soffees' Ditty is exceptionally intriguing with its use of both verse and prose.

The theoretical framework that guided this study was mainly informed by intertextuality. In intertextual studies, researchers often find the allusions and other properties of the texts in a comparative manner. Using these similar text pieces, researchers search for all the possible meanings that can be attributed to them.

The poem is composed of seven chapters. Stylistically, in The Soffees' Ditty, all prose sections begin with the writing of "Bismillah!. " Such a start to these prose sections requires further stylistic and intertextual analysis to understand its Islamic significance from a classical and traditional perspective. However, our intertextual analysis also revealed that each section preceding the parts in verse but written in prose includes various allusions to the Koran's specific verses. This reading also shows that Mangan's experiential view of Islam is closer to Sufi's rather than a traditional person's. According to this world view, human perfection is the ultimate aim of the believer. This target is also symbolically significant in forming the Sufi order that is attainable as the Sufi disciplines his carnal existence.

Our close reading of the poem showed that the speaker openly identifies himself with Sufis as he writes "we" to point at the believers, Sufis, and himself as a unified group. This use is also significant because Allah, in the Koran, uses "we" to identify himself rather than "I" as the creator. Furthermore, unlike many other poems produced in the period Mangan lived and wrote, the poem refrains from using an Orientalist point of view. The speaker, thus, is a man of the Koran. This narrator lives and speaks within the Sufi order that tells of a unique interpretation of the Koran. Such understanding is based on the genuine love of God rather than exemplifying mere obedience to the supreme being. 
Makale Bilgileri

Etik Kurul Kararı:

Katılımo Rizası:

Mali Destek:

Çıkar Çatışması:

Telif Haklarn:
Etik Kurul Kararından muaftır.

Çalışmada katılımcı yer almamaktadır.

Çalışma için herhangi bir kurum ve projeden mali destek alınmamıştır.

Çalışmada kişiler ve kurumlar arası çıar çatışması bulunmamaktadır.

Telif hakkına sebep olacak bir materyal kullanılmamıştır.

Article Information

Ethics Committee Approval: Informed Consent:

Exempt from the Ethics Committee Decision.

Financial Support:

No participants.

Conflict of Interest:

No financial support from any institution or project.

Copyrights:

No conflict of interest.

No material subject to copyright is included. 


\section{KAYNAKÇA}

Akgül, M. ve Arıkan, A. (2019). Islamic motifs in James Clarence Mangan's poems (18381844). IV. International Social Research and Behavioral Sciences, Antalya.

Aktulum, K. (2000). Metinlerarası ilişkiler. Ankara: Öteki Yayınevi.

Altıer, S. (2008). Bektaşi ikonografisi üzerine bir deneme: Hacı Bektaş Veli Müzesi'ndeki figürlü keşkül-ü fukaralar. SDÜ Fen Edebiyat Fakültesi Sosyal Bilimler Dergisi, 17, 101-116.

Altındiş, H. (2020). Shaping the way we believe: Sufism in modern Turkish culture and literature. (Der. Alam, S.) Cultural Fusion of Sufi Islam: Alternative Paths to Mystical Faith içinde. (s. 115-130). Oxon: Routledge.

Becker-Leckrone, M. (2005). Julia Kristeva and literary theory. China: Palgrave Macmillan.

Childs, P., ve Fowler, R. (2006). The Routledge Dictionary of Literary Terms. Oxon: Routledge.

Elçibey, E. ve Kemaloğlu, K. (2014). Bazı Sufi akımları hakkında. Akademik Tarih ve Düşünce Dergisi, 1(4), 1-11.

Genette, G. (1992). The Architext: An introduction. (Lewin, J.E., Çev.) USA: University of California Press.

Genette, G. (1997). Palimpsets: Literature in the second degree. (Newman, C. ve Doubinsky, C., Çev.) Lincoln and London: University of Nebraska Press.

Gezer, S. (2015). Kur'an'da geçen sayısal ifadeler hakkında bazı değerlendirmeler. Hitit Üniversitesi Sosyal Bilimler Enstitüsü Dergisi, 8(2), 477-492.

Gowins, P. (2009). Sûfilik: Ruhani yoldaki bilgilerin uygulama teknikleri. (Yıldız, A. ve Çelebi, A., Çev.) İstanbul: Şira Yayınları.

Gökpınarlı, A. (1985). 100 soruda tasavvuf. İstanbul: Gerçek Yayınevi.

Graham, A. (2011). Intertextuality. New York: Routledge.

Irwin, W. (2001). What is an allusion? The Journal of Aesthetics and Art Criticism, 59 (3), 287297.

Kristeva, J. (1980). Desire in language: A semiotic approach to literature and art. (Gora, T., Jardine, A. ve Roudiez, L.S., Çev.) New York: Columbia University Press.

Kurt, A. (2019). "Söyleyici" kavramı ve "Nûrusiyâh" şiirinden hareketle şiir çözümleme yöntemlerinde "Söyleyici"nin tespitinin şiiri anlamaya katkısı. Rumeli Dil ve Edebiyat Araştırmaları Dergisi, (14), 174-182.

Mangan, J. C. (1844). Literae Orientales: Ottoman poetry fifth article. The Dublin University Magazine, 133(23), 535-550.

Mangan, J. C. (1996). The soffees' ditty. (Der. Chuto, J., v.d.) The Collected Works of James Clarence Mangan (Poems: 1838-1844) içinde. (s. 353-355). Dublin: Irish Academic Press.

Mut, H. ve Akkuş, S. (2016). Bir Bektâşî dedebabası Bedri Noyan’a (1912-1997) göre zâhir bâtın ilişkisi. Usul İslam Araştırmaları, 25, 133-158.

Noyan, B. (1999). Bütün yönleriyle Bektaşîlik ve Alevîlik (II. Cilt). Ankara: Ardıç.

O'Donoghue, D. J. (1897). The life and writings of James Clarence Mangan. Dublin: Sealy, Bryers \& Walker.

Özer, S. (2008). Hadis metninin anlaşılmasında diğer metinlere referansların önemi ya da hadiste metinlerarasılık ve metinlerarası okuma. Dinbilimleri Akademik Araştırma Dergisi, $\operatorname{VIII}(1), 305-350$.

SEFAD, 2021; (46): 23-42 
Quinn, E. (2006). A Dictionary of Literary and Thematic Terms. New York: Fact on File.

Renard, J. (2009). The A to Z of Sûfism. USA: The Scarecrow Press.

Schimmel, A. (1978). Mystical dimensions of Islam. USA: The University of North Carolina Press.

Soya, H. R. (2015). Walter Benjamin'in mistisizmi ile tasavvuf felsefesine bir bakış. Kayğı, 25, 29-41.

Türkiye Diyanet Vakfı İslam Ansiklopedisi. Seyyid. Erişim:

https://islamansiklopedisi.org.tr/seyyid

Türkiye Diyanet Vakfı İslam Ansiklopedisi. Tasavvuf. Erişim:

https://islamansiklopedisi.org.tr/Tasavvuf

Üçok, B. (1968). İslâm Tarihi: Emevîler Abbasîler. Ankara: Ankara Üniversitesi İlâhiyat Fakültesi Yayınları.

Yaşar, H. (2016). Alaeddin Ali Semerkandi (Karamani)'nin tefsire katkısı. (Der. Şeker, M., Mercan, M., Kaya, Y. ve Uncu, C.) Karamanoğulları Beyliği içinde. (s. 260-277). Konya: Necmettin Erbakan Üniversitesi. 